\title{
Serological survey of Infectious Bursal Disease Antibodies amongst birds in Keffi, Nassarawa State, Nigeria
}

\author{
*Olabode H.O. K ${ }^{1}$,, Ameh J. A' ${ }^{1}$, Abraham S. U., ${ }^{1}$ and Elayo S. A. ${ }^{2}$ \\ ${ }^{1}$ Department of Microbiology, Faculty of Veterinary Medicine, University of Abuja \\ ${ }^{2}$ Department of Virology, Federal College of Animal and Medical laboratory, N.V.R.I Vom \\ DOI:10.36108/jvbs/8102.10.0150
}

\begin{abstract}
Infectious Bursal Disease (IBD) is an acute, immunosuppressive disease of significant threat to the poultry industry in Nigeria and vaccination has been reported as the best method of control. This study was conducted between November and December 2015 to establish the occurrence of infectious bursal disease antibodies in exotic chickens from some selected backyard poultry farms and local chickens slaughtered in keffi central market, Nassarawa State. Sera collected randomly from two hundred birds were subjected to Agar Gel Precipitation Test (AGPT) for qualitative analysis at the virology laboratory (FCVMLT), National Veterinary Research Institute, Vom. The assay showed 35\% of exotic birds had IBD virus antibodies while local birds indicated absence of detectable antibodies with significant $P<0.05$ breed association $\left(X^{2}=42.5, d f=2\right)$. However, there was no association $(P>0.05)$ with age in both breeds and IBDV antibodies $\left(X^{2}=0.802,3.13, d f=1\right)$. The presence of antibodies in exotic breeds suggests evidence of post vaccination protective antibodies due to sero-conversion rather than anti-IBDV antibodies associated with disease. Absence of infectious bursal disease virus antibodies in local birds suggests high vulnerability to potential IBD outbreaks posing a risk of financial losses to stakeholders. In conclusion, this sero-survey of Infectious bursal disease antibodies in exotic birds suggest evidence of vaccination and the need to vaccinate local birds. Awareness campaign program amongst rural and backyard poultry keepers in the study community on the need to protect their commercial exotic and free scavenging birds against infectious bursal disease is thus recommended.
\end{abstract}

Key words: Infectious bursal disease, Agar Gel Precipitation Test (AGPT), birds, Keffi

*Corresponding email: olabodeok@yahoo.com

Tel: $+234(0) 8023806741$

This Paper was accepted on 15th November, 2017 and published 24th April, 2018 


\section{Sero - Survey of Infectious Bursal Disease Antibodies}

\section{INTRODUCTION}

Infectious Bursal Disease Virus (IBDV) is an important viral disease of global threat to the poultry industry [1] including Africa [2] and Nigeria [3]. IBD virus is a non-enveloped double stranded RNA (dsRNA) virus belonging to the genus Avibirnavirus of the family Birnaviridae. There are two known non-cross protective nor neutralizing serotypes of IBDV, Serotype 1 is pathogenic to chickens which causes IBD, while serotype 2 is apathogenic [4]. IBD is characterized by blackish brown, haemorrhagic and enlarged bursa of Fabricius and in some birds the bursa may contain flakes of pus, haemorrhages in the thigh, breast, leg, wing muscles and in the clocal bursa (bursa of Fabricius) [5]. Clinical IBD manifests in chickens between 3 and 6 weeks of age which may result in death. However, subclinical infections occur in birds less than 3 weeks of age. Although, the disease have also been observed in chickens older than 6 weeks and up to 20-week-old [6]. Both male and female chickens are equally susceptible to IBD [7] which occurs in rainy and dry seasons of the year [8]. Other susceptible birds include ducks, guinea fowl, turkey, pigeons [9] and wild birds [10]. Clinical manifestations and postmortem findings in affected birds may aid diagnosis of IBD but laboratory diagnosis is necessary for confirmation. Serological $\mathrm{d}$ i a g n o s t c methods $1 \mathrm{ike}$ i m mu ohis to chemistry [ 111$]$, haemagglutination inhibition (HI) test, indirect haemagglutination (IHA) test, agar gel immunodiffusion test (AGIDT) [12], virus neutralization test (VNT), fluorescent antibody technique (FAT), plaque reduction neutralization test (PRNT), enzyme linked immunosorbent assay (ELISA) [13] and Counter immunoelectrophoresis tests [14] have been used. These techniques allow for reliable and accurate identification of most suspicious samples as they are sensitive and specific methods to detect and confirm IBD [12]. In Nigeria, control of infectious bursal disease is based on vaccination with live vaccines from foreign infectious bursal disease virus (IBDV) strains, however, frequent outbreaks of infectious bursal disease in both vaccinated [15] and unvaccinated [16] chicken flocks continue to occur. Prophylactic use of antibiotic has been the most widely practiced intervention protocol during IBD outbreaks to curb secondary bacterial infections with little and or guarded prognosis. This indiscriminate antibiotic use constitutes a growing public health problem and heavy financial losses to poultry industry [17]. Previous serological evaluation of IBD indicated varied occurrences across the country [16], [8], [7], [1]. The paucity of IBD information status in the study area necessitated this serological survey to determine the infectious bursal disease virus antibody titres in both exotic and local (Nigerian indigenous) breeds of birds in Keffi, Nassarawa State of Nigeria, a gateway town to the nation's Federal capital, Abuja.

\section{MATERIALS AND METHODS}

\section{Study Area}

The study was carried out in Keffi, Keffi Local Government Area of Nassarawa State which was created in 1996 from the neighboring Plateau State, located in the North-Central Nigeria. Nasarawa State is bordered on the 


\section{Sero - Survey of Infectious Bursal Disease Antibodies}

West by the Federal Capital Territory (FCT), the North by Kaduna, the South by Benue and Kogi and the East by Plateau and Taraba State [18].

\section{Study design}

A cross sectional study was conducted for the qualitative detection of IBD antibodies in both exotic and local breeds of chickens in Keffi. Exotic commercial broilers (50) within $6-11$ weeks and layers (50) within 25 - 50 weeks of age with history of IBD vaccination using foreign vaccines were randomly sampled from some selected backyard poultry farms while slaughtered local birds (100) were randomly sampled at the Keffi Central Market. This survey was conducted between November and December, 2015. These selected chickens were grouped according to breeds and age prior to sample collection.

\section{Sample Collection}

Blood was collected using 5mls Syringe and $21 \mathrm{G} 1_{2}^{1 /}$ needle through the wing vein from restrained exotic birds (broilers and layers) while blood from local birds were collected post slaughter. All the blood samples were transferred into different labeled plain sample bottles and kept at an angle of $45^{\circ}$ at room temperature for sera separation. Post clotting, the sera were aspirated into another set of cryovials using another set of micropipette, then labeled and stored at $4^{\circ} \mathrm{C}$. The sera were then ice packed for onward transportation and analysis at the Virology Laboratory, Federal College of Veterinary and Medical Laboratory Technology (FCVMLT) N.V.R.I, Vom.

\section{Agar Gel Precipitation Test}

The sera were subjected to Agar gel precipitation test to detect Infectious bursal disease antibodies as previously described [8] and post preparation of Agarose (1\% Iron Agar) in accordance with NVRI, Vom Standard Operating Procedures (SOP).

Briefly, the agar was placed on the template and wells bored using the plate or agar borer. The various wells were labeled accordingly with the central well labeled as "standard" and the top and bottom wells labeled "Positive $(+)$ and Negative (-)" respectively. The other wells were labeled $\mathrm{T} 1$ to $\mathrm{T} 4$ accordingly. The central well was filled with antigen (bursal homogenates) using Pasteur pipette. The test sera $(50 \mu \mathrm{l})$ were dispensed into the wells and $50 \mu \mathrm{l}$ of positive and negative controls were also dispensed into the opposite wells. The plates were later incubated in a humid chamber at room Temperature $\left(25^{\circ} \mathrm{C}\right)$ for $24-48 \mathrm{hrs}$, while positive precipitation bands were checked for at 24 hour interval against illuminated source. Positive samples showed precipitin lines between samples and viral antigen wells. The intensity of reaction was recorded and interpreted as previously documented [9]

\section{Data Analysis}

The numbers of positive samples were expressed as simple descriptive statistics such as frequency and percentages. Chi square was applied to establish the association of IBD virus antibodies between the groups of birds. 


\section{RESULTS}

Table I: Distribution of IBD virus antibodies amongst exotic and local chickens in the study area

\begin{tabular}{lllll}
\hline Breeds & Birds sampled & Positive & Negative & Percentage (\%) \\
\hline Local birds & 100 & 0 & 100 & 0 \\
Broilers (exotic) & 50 & 17 & 33 & 66 \\
Layers (exotic) & 50 & 18 & 32 & 64 \\
\hline Total & $\mathbf{2 0 0}$ & $\mathbf{3 5 ( 3 5 \% )}$ & $\mathbf{1 6 5}$ &
\end{tabular}

Table II: Age distribution of IBD virus antibodies amongst broilers (exotic) chickens in the study area

\begin{tabular}{lllll}
\hline Age (weeks) & Birds sampled & Positive & Negative & Percentage (\%) \\
\hline $6-8$ & 25 & 10 & 15 & 20 \\
$9-11$ & 25 & 7 & 18 & 14 \\
\hline Total & $\mathbf{5 0}$ & $\mathbf{1 7}$ & $\mathbf{3 3}$ & $\mathbf{3 4}$ \\
\hline
\end{tabular}

Table III: Age distribution of I BD virus antibodies amongst layers (exotic) chickens in the study area

\begin{tabular}{lllll}
\hline Age (weeks) & Birds sampled & Positive & Negative & Percentage (\%) \\
\hline $25-36$ & 25 & 12 & 13 & 26 \\
$>37-50$ & 25 & 6 & 19 & 10 \\
\hline Total & $\mathbf{5 0}$ & $\mathbf{1 8}$ & $\mathbf{3 2}$ & $\mathbf{3 6}$ \\
\hline
\end{tabular}

All the sera from local birds subjected to AGPT were negative without IBD virus antibodies as shown in Table I. Exotic chickens sampled showed 34\% (17) broilers and 36\% (18) layers were positive for IBD virus antibodies. The distribution of exotic species (broilers and Layers) and age with respect to IBD virus antibodies is as shown Tables II and III. Chi square analysis further showed significant $\mathrm{P}<0.05$ breed association $\left(\mathrm{X}^{2}=\right.$ 42.5, $\mathrm{df}=2$ ) Table I. However, there was no association $(\mathrm{P}>0.05)$ with age of both exotic species and IBDV antibodies $\left(\mathrm{X}^{2}=0.802,3.13\right.$ df=1) Tables II and III.

\section{DISCUSSION}

The overall sero-prevalence of IBD in this study was $35 \%$ for exotic chickens (both layers and broilers) as shown in Table I using AGPT. 


\section{Sero - Survey of Infectious Bursal Disease Antibodies}

The observed precipitation in $34 \%$ of broilers and $36 \%$ of layers screened indicates serological evidence of infectious bursal disease antibodies among exotic breeds in Keffi metropolis. This finding is lower (41.1\%) in comparison with that recorded in Sudan [14] from commercial birds. The $34 \%$ for broilers and $36 \%$ for layers seropositivity in this study is in line with $34.7 \%$ and $40.35 \%$ respectively for layers and broilers recorded in Grenada, West Indies [19], although using ELISA but higher than $6.42 \%$ for broilers reared in a rural setting in Nsukka, Eastern-Nigeria [3]. The observed unequal degree of precipitations in the sera studied which suggests disproportionate levels of immune responses amongst birds to IBDV. The infectious bursal disease antibodies in this study birds could not have been associated with maternally derived antibodies (MDA) that usually persists for 7 days and completely decay between 10 - 13 days as determined by ELISA [20] because birds considered in this study were within the age range of 7-8 weeks and 9-11 weeks for broilers and $>50$ weeks for layers respectively. Therefore, antibodies detected in the birds within 7-11 weeks suggests both effective vaccine sero-conversion and vaccination against infectious bursal disease as there exists a correlation between antibody titres and protection [21] confirming the use of IBD vaccines and vaccination as a routine control protocol adopted by the farmers in this area. This may explain the resultant high IBD seroprevalence in the exotic birds as previously reported in vaccinated commercial broilers in some regional urban areas [3], suggesting vaccination age has more impact on antibody build up post vaccination in young birds as vaccinates show full protection when vaccinated on day 21 and boosted on day 28 [22] as seen in 7-11 weeks birds sampled in this study. Although, birds within 3-6 weeks have been reported to be more susceptible to clinical disease [23] with reports of IBDV outbreaks characterized by high mortality in vaccinated layer birds (28-35 days old) following absence and or low vaccinal immunity due to antigenic differences in field circulating IBD virus and non-homologous vaccine strain commonly used for vaccinations [24].

Previous report indicates reoccurrence of infectious bursal disease in 15 week old birds [25] suggesting these observed antibodies could be anti-infectious bursal disease virus antibodies in birds over 20 - 50 weeks of age following infection due to non-vaccination or administration of booster doses in adult birds with in-active bursa of fabricus. There also exists the possibility that IBD antibodies observed in these birds $>50$ weeks were humoral antibodies due to IBD vaccination as reported in layering birds between 22-60 weeks post vaccinations [26]. Therefore, IBD antibody in older birds suggests occurrence of sub clinical infection which is the most important form of IBD causing immunosuppression and susceptibility to other diseases [27] with economic and epidemiological significance. Although, this serological test could not distinguish between 
antibodies induced by pathogenic infectious bursal disease virus and those induced by attenuated vaccines, serological IBD antibody detection is of particular importance in endemic regions especially Nigeria [9].Species susceptibility in this study also numerically indicates that more adult layering birds had IBDV antibodies as compared with the broilers, although not significant $(\mathrm{P}>0.05)$ but confirms previous report [19].

The findings of this study also show no serological evidence of infectious bursa disease in local birds within this area. This is similar to the zero prevalence found among backyard local chickens in Dongola, Northern Sudan [14] for there exist the possibility that at the particular time of sampling the birds were not exposed to the virus and hence IBD antibodies were not detectable by AGPT as agar gel precipitation test can detect viral antigen in the bursa of Fabricius in the early stages of infection before the development of an antibody response [28].

It also implies that the local birds screened were not exposed to IBD vaccines as this finding may not reflect true prevalence and contrasts previous reports across the country as shown in the occurrence of $9.58 \%$ in Northeastern-Nigeria [9], 51.6\% in Udu LGA, Delta state [1], 63.5\% in Gombe State [7], $41.0 \%$ in Nsukka [8] and $89.7 \%$ amongst unvaccinated local birds in Abeokuta, South Western Nigeria [16] as well as other parts of Africa including Tanzania, 58.5\% [13],
Ethiopia 91.9\% [29] and 91.8\% in Sinar, Sudan [2]. This observed inconsistency could also be associated with the sampling method, sample size, coverage within study area, volume of human settlement and traffic, local poultry trade as well as duration of study. Although, previous report corroborates lower serological IBD occurrence in the local birds in comparison with exotic breeds [23] as well as lower occurrence in rural areas than urban settlement [7].

In conclusion, the findings of this study revealed no serological evidence of the infectious bursa disease in local birds. The study however, documents both vaccine seroconversion and potential sub-clinical infection in young and adult exotic chickens respectively within the study area. In addition it also indicates that AGPT serological test is of diagnostic significance as a simple, accurate means of detecting both clinical and sub clinical infections. There is the need for public enlightenment program amongst rural and backyard poultry keepers in the study community to protect their free scavenging local and commercial exotic birds against infectious bursal disease.

\section{REFERENCES}

1. Abraham-Oyiguh, J., Adewumi, M.O., Onoja, A.B., Suleiman, I., Sulaiman, L.K., Ahmed, S.J., and Jagboro, S.T. (2015).Seroprevalence of Infectious Bursal Disease Virus in Local Chickens in Udu Local Government Area of Delta State, South East Nigeria. Journal of Immunoassay and 


\section{Sero - Survey of Infectious Bursal Disease Antibodies}

Immunochemistry, 36(4): 398-404.

2. Selma, O.A and Ballal, A. (2013) Seroprevalence of Selected Avian Pathogens of Backyard Poultry in Sinar, Sudan. Bulletin of Animal Health and Production in Africa, 61(2): 209-214.

3. Okwor, E. C., Eze, D.C., Okoye, C.N., Chah, K.F., and Ibu, J.O. (2016). Seroprevalence of Infectious Bursal Disease Antibodies in Grown broilers reared in rural areas of South Eastern Nigeria. International Journal Biology Pharmacy Allied Sciences, 5(10): 2430-2440.

4. Eterradossi, N. and Saif, Y.M. (2008)"Infectious bursaal disease," In Disease of Poultry, Y. M. Saif, A. M. Fadly, J. R. Glisson, L. R. McDougald, L. K. Nolan, and D. E. Swayne, Eds., 12th edition, Blackwell Publishing, Ames, Iowa, USA, pp. 185-208.

5. Hajare, S. A. (2014) Molecular Characterization of Infectious Bursal Disease Virus (Ibdv) Isolates (Doctoral dissertation, MAFSU)

6. Mutinda, W. U., Nyaga, P. N., Njagi, L. W., Bebora, L. C., and Mbuthia, P.G. (2013). Gumboro disease outbreaks cause high mortality rates in Indigenous chickens in Kenya. Bulletin of AnimalHealth Production Africa, 61: 571-578

7. Lawal, J.R., Jajere, S.M., Bello, A.M. Mustapha, M.,Wakil, Y., Ndahi, J.J., Mustapha, F.B., Paul, B.T., Gulani, I.A.,Ibrahim, U.I., Geidam, Y.A., Ambali, A.G., and Waziri, I. (2014). Prevalence of Infectious Bursal Disease (Gumboro) Antibodies in
Village Chickens in Gombe State, Northeastern Nigeria. International Journal of Poultry Science, 13 (12):703-708.

8. Anosa, G.N and Eze, J.I (2010)A SeroEpidemiological Survey of Infectious Bursal Disease in Scavenging Village Chickens in Enugu State, Nigeria. Nigerian Veterinary journal, 31(4): 267-270.

9. Chukwuedo, A.A., Nwanki, O.O., Ibu, J.O., and Asala, O.O. (2016). Serological Detection of Infectious Bursa Disease Virus Antibodies in Domestic Birds in North Central States of Nigeria. Nigerian Journal of Biotechnology, 31(1): 9-14.

10. Jeon, W. J., Lee, E.K., Joh, S. J., Kwon J. H., Yang, C. B., Yoon, Y. S., and Choi, K. S. (2008). Very virulent infectious bursal disease virus isolated from wild birds in Korea: epidemiological implications. Virus Research, 137(1):153-6.

11. Oladele, O. A., Adene, D. F., Obi T.U., Nottidge, H. O. (2009). Comparative susceptibility of chickens, turkeys and ducks to infectious bursal disease virus using immunohistochemistry. Veterinary Research Communications, 33(2):111-21.

12. Rakibul Hasan, A. K. M., Ali, M. H., Siddique, M. P., Rahman, M. M., and Islam, M. A. (2010). Clinical and Laboratory diagnoses of Newcastle and Infectious Bursal Diseases of Chickens. Bangladesh Journal Veterinary Medicine, 8(2): 131-140.

13. Swai, E. S., Kessy, M.J., Sanka, P.N., and Mtui, P.F. (2011). A serological 
survey for infectious bursal disease virus antibodies in free-range village chickens in northern Tanzania. Journal of the South African Veterinary Association, 82(1): 32-35.

14. Rahman, M.E.A., Elazomi, A., Shawesh, F., and Hussien, M. (2016).Seroprevalene of Infectious Bursal Disease in Exotic and Backyard Chicken's Sera Collected from Some Parts of Sudan, tested by the Agar-Gel Precipitation and Counter immunoelectrophoresis Tests. Imperial Journal of Interdisciplinary Research, 2(5): 85-89

15. Adamu, J., Owoade, A. A., Abdu, P.A., Kazeem, H.M., and Fatihu, M. Y. (2013). Characterization of field and vaccine infectious bursal disease viruses from Nigeria revealing possible virulence and regional markers in the VP2 minor hydrophilic peaks. Avian Pathology, 42(5):420-33.

16. Oni, O. O., Ajayi, O. L., and Ogunyeye, I. T. (2008). Serological status of Unvaccinated Indigenous Chickens for Infectious Bursal Disease Virus Antibody in Abeokuta. An International Journal of Agricultural sciences, Sciences Environment and Technology, 8(2):213-237.

17. Musa, I.W., Saidu, L., Adamu, J., Mbuko, I.J., Kaltungo, B.Y., and Abdu, P.A (2010). Outbreaks of Gumboro in Growers in Zaria, Nigeria. Nigerian Veterinary Journal, 31:306-310.

18. Anon (2015) KEFFI, Nasarawa State https://en.wikipedia.org/wiki/Keffi

19. Sharma, R.N., Tiwari, K.P., Chikweto,
A., Thomas, D., DeAllie, C., Stratton, G., and Bhaiyat, M.I (2014). Seroprevalence of Five Important Viral Diseases inCommercial Chickens in Grenada, West Indies.International Journal of Poultry Science, 13 (5): 299-303.

20. Moraes, H.L.S., Salle, C.T.P., Nascimento, V.P., Salle, F.O., Rocha, A.C.G.P., Souza, G.F., Furian, T.Q., and Artencio, J.O (2005). Infectious Bursal Disease: Evaluation of Maternal Immunity and Protection by Vaccination of One-Day Old Chicks Against Challenge with a Very Virulent Virus Isolate. Brazilian Journal of Poultry Science, 7 (1):5157.

21. Camilotti, E., Moraes, L.B., Furian, T.Q., Borges, K.A., Moraes, H.L.S., and Salle, C.T.P (2016). Infectious Bursal Disease: Pathogenicity and Immunogenicity of VaccinesBrazilian Journal of Poultry Science (Revista Brasileira de Ciência Avícola), 18 (2): 303-308.

22. Besseboua, O., Ayad, A. and Benbarek, H., (2015). Determination of the optimal time of vaccination against infectious bursal disease virus (Gumboro) in Algeria. Onderstepoort Journal of Veterinary Research82(1): $\mathrm{h} \mathrm{t} \mathrm{t} \mathrm{p}: \mathrm{/} / \mathrm{d} \mathrm{x} . \mathrm{d} \mathrm{o} \mathrm{i}$. org/10.4102/ojvr.v82i1.887, 6pages.

23. Tadesse, B. and Jenbere, S. (2014). Sero-Prevalence of Infectious Bursal Disease in Backyard Chickens at Selected Woredas of Eastern Ethiopia.Journal of Biology, Agriculture and Healthcare, 4 (17): 70-75.

24. Aliyu, H.B., Sa'idu, L., Jamilu A., Andamin, A.D., and Akpavie, S.O 
(2016). Outbreaks of Virulent Infectious Bursal Disease in Flocks of Battery Cage Brooding System of Commercial Chickens. Journal of $\begin{array}{llllllllll} & e & t & e & r & i & n & a & r & y\end{array}$ Medicine, http://dx.doi.org/10.1155/20 $\underline{16 / 8182160} 7$ pages.

25. Shekaro, A. and Josiah, I. E. (2015). Infectious Bursal Disease Outbreak in Fifteen Weeks Old Pullets in Kaduna, Nigeria. Journal of Animal Production Advances, 5(3): 636-644

26. Parker, D., and de Wit, S. (2014). Assessment of impact of a novel infectious bursal disease (IBD) vaccination programme in breeders on IBD humoral antibody levels through the laying period. Veterinary Record O p e n 1: e 000016 . d o i : 10.1136/vropen-2013-000016.

27. Uddin, S.N., and Hossain, S.A. (2006).
Effect of infectious bursal disease virus on in vitro propagation of chicken embryo fibroblast cells. Asian Journal of Animal and Veterinary Advances, 1: 55-59.

28. Mutinda, W. U., Njagi, L. W., Nyaga, P. N., Bebora, L. C., Mbuthia, P. G., Kemboi, D. Githinji, J. W.K., and Muriuki, A. (2015). Isolation of Infectious Bursal Disease Virus Using IndigenousChicken Embryos in Kenya. International Scholarly Research Notices, 1-7

29. Chaka, H., Goutard, F., Bisschop, S. P., and Thompson, P. N. (2012) Seroprevalence of Newcastle disease and other infectious diseases in backyard chickens at markets in Eastern Shewa zone, Ethiopia. Poultry Science, 91(4):862-869. 